\title{
Pollen Dispersal and Pollination Patterns Studies in Pati Kopyor Coconut using Molecular Markers
}

\author{
Siti Halimah Larekeng ${ }^{1,2}$, Ismail Maskromo ${ }^{1,3}$, Agus Purwito ${ }^{1}$, Nurhayati Anshori Matjik ${ }^{1}$, \\ and S. Sudarsono ${ }^{1}$
}

\begin{abstract}
Parentage analysis has been used to evaluate pollen dispersal in Kopyor coconut (Cocos nucifera L.). Investigations were undertaken to elucidate (i) the dispersal of pollen, (ii) the rate of self and outcrossing pollination, and (iii) the distance of pollen travel in Pati kopyor coconut population. The finding of this activities should be beneficial to kopyor coconut farmers to increase their kopyor fruit harvest and to support breeding of this unique coconut mutant. As many as 84 progenies were harvested from 15 female parents. As many as 95 adults coconut provenances surrounding the female parents were analyses as the potential male parents for the progenies. The adult coconut palms were mapped according to their GPS position. All samples were genotyped using six SSR and four SNAP marker loci. Parentage analysis was done using CERVUS version 2.0 software. Results of the analysis indicated that evaluated markers were effective for assigning candidate male parents to all evaluated seedlings. There is no specific direction of donated pollen movement from assigned donor parents to the female ones. The donated pollens could come from assigned male parents in any directions relative to the female parent positions. Cross pollination occured in as many as $82.1 \%$ of the progenies analyzed. Outcrossing among tall by tall (TxT), dwarf by dwarf (DxD), hybrid by hybrid $(\mathrm{HxH})$, TxD, DxT, TxH, DxH, and HxD were observed. Self-pollination (TxT and DxD) occurred in as many as $17.9 \%$ of the progenies. The dwarf coconut was not always self pollinated. The presence of $\mathrm{DxD}, \mathrm{TxD}$, and $\mathrm{HxD}$ outcrossing was also observed. The donated pollens could come from pollen donor in a range of at least 0-58 $\mathrm{m}$ apart from the evaluated female recipients. Therefore, in addition to the wind, insect pollinators may have played an important role in Kopyor coconut pollination.
\end{abstract}

Keywords: Coconut mutant, abnormal endosperm, parentage analysis, pollen movement, outcrossing rate, self pollination, SSR marker, SNAP marker

\footnotetext{
${ }^{1}$ PMB Lab., Department of Agronomy, Fac. of Agriculture, IPB, Bogor, Indonesia.

${ }^{2}$ Fac. Of Forestry, Hasanuddin University, Makasar, Indonesia.

${ }^{3}$ Indonesian Palm Research Institute, Agency for Agricultural Research and Development (AARD), Manado, Indonesia.

Corresponding author:

S. Sudarsono, PMB Lab., Department of Agronomy, Fac. of Agriculture, IPB, Jl. Meranti - Darmaga Kampus, Bogor 16680, Indonesia. Ph./Fax. 62-251-8629353; Email: s_sudarsono@ymail.com
} 


\section{Introduction}

Kopyor coconuts are natural coconut mutants having abnormal endosperm and only exist in Indonesia. The endosperm is soft, crumbly and detached from the shell, forming flakes filling up the shell (Maskromo et al. 2007; Novarianto et al. 2014). The Makapuno coconut grown in the Philipines and other Asian countries is another example of coconut mutant exhibiting endosperm abnormality (Samonthe et al. 1989; Wattanayothin, 2010). This mutant has been used as parent for hybridizations in coconut breeding (Wattanayothin, 2005). The Macapuno coconut exhibits a soft and jelly-like endosperm (Santos, 1999) that is phenotypically different to Indonesian Kopyor coconut.

The kopyor coconut mutant phenotype is genetically inherited from parents to their progenies (Sukendah 2009) and most probably is controlled by a single locus (K locus) regulating the endosperm development of coconut (Sudarsono et al. 2014). However, the identity of the regulatory locus has not yet been resolved.

The abnormal endosperm phenotype in kopyor coconut is controlled by the recessive $\mathrm{k}$ allele; therefore, the genotype of kopyor fruit of coconut would be homozygous kk for the zygotic embryos and homozygous kkk for the endosperm. On the other hand, the genotype of the normal fruit of coconut would either be a homozygous $\mathrm{KK}$ or a heterozygous $\mathrm{Kk}$ for the zygotic embryo and either a homozygous KKK, heterozygous $\mathrm{KKk}$, or heterozygous Kkk, respectively.

The origin of Kopyor coconut mutant is not well documented; however, currently the kopyor palms are found in a number of areas in Java and southern part of Sumatera (Novarianto and Miftahorrachman 2000). The district of Pati, Central Java Province is recognized as one of the Kopyor coconut production centers. Kopyor coconuts have existed in this region for generations, especially the dwarf type of Kopyor coconuts. Although only in a limited numbers, Kopyor Tall and Kopyor Hybrid coconut types also exist along side of the dwarf one.

The tall and dwarf coconut have different morphological characters and pollination strategy. Tall coconuts are generally outcrossing since male flower mature earlier than the female counterpart in the same inflorescence. Dwarf coconut tends to self-pollinate because of an overlapping maturation period between male and female flowers (Deb Mandal and Shyamapada 2011).

Pollination in coconut most probably is assisted by insect pollinators or by the wind (Ramirez et. al. 2004). The family of Diptera, Coleoptera and Hymenoptera are reported as effective pollinators of coconut (Ramirez et al. 2004). Distances of pollen transfer between male and female parents may be used to predict the type of pollinator assisting pollination in coconut. Such question may be answerred by studying pollen dispersal.

Evaluating pollen dispersal in various plant species usually use an approach based on the parent - progeny genotype genotype (Austerlitz et al. 2004). Evaluations have been done in pines (Schuster and Mitoon 2000), Dinizia excels - Fabaceae (Dick et al. 2003), Quercus garryana - Fagaceae (Marsico et al. 2009) and teak (Prabha et al. 2011). Availability of molecular markers capable of identifying genotype of parents and their progenies should assist the pollen dispersal studies. Using such markers, it should also be possible to estimate the self-pollination and outcrossing rates in a certain population (Milleron et al. 2012).

To our understanding, pollen dispersal analysis has not been evaluated in coconuts. With the development of kopyor coconut in Indonesia, availability of information associated with pollen dispersal should be beneficial considering the recessive nature of the kopyor character. Such coconut pollen dispersal evaluation requires availability of some coconut progeny arrays and polymorphic loci for molecular markers of coconut genome.

Co-dominant markers, such as SSR and SNAP markers for coconut have been developed and routinely evaluated at PMB Lab, Department of Agronomy and Horticulture, Faculty of Agriculture, Bogor Agricultural University (IPB), Bogor, Indonesia for a number of plant species. These include coconut (Sudarsono et al. 
2014), cacao (Kurniasih 2012), and nut meg Myristica sp. (Soenarsih 2012). Moreover, the gene specific SNAP markers have also been developed and used successfully in coconut (Sudarsono el al. 2014).

The SSR markers have successfully been used in gene flow analysis of pines (Lian et al. 2001; Burczyk and Koralewski. 2005). SNAP marker have also been reported as an effective co-dominant marker for plant analysis (Morin et al. 2004, Sutanto et al. 2013) and proven to generate better data quality for the majority of samples on plant genetic studies (Brumfield et al. 2003) and population structure analysis (Herrera et al. 2007).

The objectives of this research were is to evaluate (i) the dispersal of pollen, (ii) the rate of self and out-crossing pollination, and (iii) the distance of pollen travel in Pati kopyor coconut population. The finding of these activities should be beneficial to kopyor coconut farmers to increase their kopyor fruit yield and to support breeding and cultivar development of this unique mutant.

\section{Materials and methods}

\section{Time and Location of Research}

This research was conducted during the period of July 2012 up to January 2014. The field activities were at the Kopyor coconut plantation belonging to local farmer's at Sambiroto, Pati District, Central Java, Indonesia. The research site was at the following GPS location: S 632.182 E 11 03.354. The soil in the evaluated Kopyor coconut plantation is sandy soil. The laboratory activities were done at Plant Molecular Biology Laboratory (PMB Lab), Department of Agronomy and Horticulture, Faculty of Agriculture, Bogor Agricultural University, Bogor, Indonesia.

\section{Selection of Parents and Progeny Arrays}

There were 164 adult coconut trees in the field research site, consisted of a mixture of both kopyor heterozygous $\mathrm{Kk}$ and normal homozygous KK coconut trees. Only 95 out of 164 adult coconut trees in one block of 100x100 $\mathrm{m}^{2}$ were sampled in this evaluation. Based on the coconut type, the sampled population consisted of 68 dwarf, 14 tall and 13 hybrid coconuts. Moreover, based on their phenotype, they were recognized as 22 normal homozygous $\mathrm{KK}$ and 73 kopyor heterozygous $\mathrm{Kk}$ coconuts. Map of the existing coconuts in the research site was generated using the GPS position of all individuals.

Six dwarf, seven tall, and two hybrid coconuts among the kopyor heterozygous $\mathrm{Kk}$ trees were selected as female parents. They were selected using purposive random sampling to represent different sites in the sampled population. A single fruit bunch from each female parent containing 2-10 fruits/bunch was harvested 10-11 months after pollination. The total harvested fruits were collected and identified as either kopyor or normal fruits. The identified normal fruits were germinated and DNA was isolated from leaf tissue of the germinated seedlings (63 seedlings of normal fruits). The kopyor fruits are not able to naturally germinate since this character is lethal. Zygotic embryos were isolated from the identified kopyor fruits and DNA was isolated directly from the whole zygotic embryo tissues (21 zygotic embryos). Among the 84 DNA samples, 26 samples were from tall, 45 from dwarf, and 13 from hybrid female parents.

\section{Genotyping of Parents and Progenies}

DNA isolation was conducted using the CTAB method (Rohde et al. 1995). Either young coconut leaf or zygotic embryo (0.3-0.4 g) was homogenized in $2 \mathrm{ml}$ of lysis buffer, containing $0.007 \mathrm{~g}$ PVP and $10 \mu 12$-mercaptoetanol. The homogenized tissues were then incubated in $65^{\circ} \mathrm{C}$ waterbath for 60 minutes and the mixtures were centrifuged at $11000 \mathrm{rpm}$ for 10 minutes using using the Eppendorf 5416 centrifuge. Supernatant was then transferred to an Eppendorf tube and an equal volume of chloroform:isoamyl-alcohol (24:1) was added. The mixtures were mixed well; centrifuged at $11000 \mathrm{rpm}$ for 10 minutes and the supernatant was transferred into new microtube.

Cold isopropanol (0.8 volume of supernatant) and sodium acetate ( 0.1 volume of supernatant) were added into the supernatant. 
After overnight incubation, the mixture was centrifuged at $11000 \mathrm{rpm}$ for 10 minutes and DNA pellet was retained. The DNA pellet was washed using $500 \mu \mathrm{l}$ of cold $70 \%$ ethanol, centrifuged and air dried before it was diluted into100 $\mu \mathrm{l}$ aquabidest. RNA contaminants were remove using RNase treatment following standard procedures (Sambrook and Russel 2001).

SSR marker at 37 loci (Lebrun et al. 2001) were evaluated for their polymorphism 6 polimorphic loci were selected. In addition, four SNAP marker loci developed based on nucleotide sequence variabilities of both SUS and WRKY genes were also used to genotype all of the parents and progeny arrays. To generate markers, PCR amplifications were conducted using the following reaction mixtures: $2 \mu \mathrm{l}$ of DNA; $0.625 \mu 1$ of primers, $6.25 \mu 1$ PCR mix (KAPA Biosystem), and $3 \mu \mathrm{l}$ ddH20. Amplifications were conducted using the following steps: one cycle of pre-amplification at $95^{\circ} \mathrm{C}$ for 3 minutes, 35 cycles of amplification steps at $95^{\circ} \mathrm{C}$ for 15 seconds (template denaturation), annealing temperature for 15 seconds (primer annealing), and $72^{\circ} \mathrm{C}$ for 5 seconds (primer extension), and one cycle of final extention at $72^{\circ} \mathrm{C}$ for 10 minutes as suggested by KAPA Biosystem kit.

The generated SSR markers were separated using vertical $6 \%$ polyacrilamide gel electrophoresis (PAGE) using SB 1x buffer (Brody and Kern 2004) and stained using silver staining. The silver staining was done following methods developed by Creste et al. (2001). Electrophoregrams were visualized over the light table and used to determine the genotype of the evaluated samples.

The generated SNAP markers were separated using $1 \%$ agarose gel electrophoresis using TBE $1 \mathrm{x}$ buffer and stained using standard DNA staining procedures (Sambrook and Russel 2001). The electrophoregrams were visualized over the UV transluminescence table and recorded using digital camera. The recorded pictures were used to determine the genotype of the evaluated samples.

\section{Identification of the Candidate Male Parents}

Each sample of the progeny arrays has a known female parent but unknown pollen donor (the male parent). The candidate male parents could be any one of the sampled adult population including the female parents. Studies were conducted to determine the assigned male parent donating pollen to generate any fruit in the progeny arrays.

Identification of the assigned male parent was done by analyzing genotype of progeny and the respective female parent versus the genotype of all adult trees in the selected samples. The ID of the potential male parent for any progeny was determine based on the results of parentage analysis. Simulation was conducted to determine the threshold level for confidence interval of $80 \%$ (relax) and 95\% (strict) levels before the final parentage analysis steps. Parentage analysis using the genotype of progenies, female parents, and potential male parents was done using CERVUS version 2.0 software (Marshall et al. 1998). Most likely approach (potential male parent with the highest LOD score) based on the matching genotype of progeny, female parent and potential male parent were used as the basis for assigning certain adult individual as the potential male parent or pollen donor of a progeny. The progeny and female parent genotype were compared with those of other adult trees and the assigned male parent was selected based on the output of CERVUS version 2.0 analysis results (Marshall et al. 1998).

\section{Pattern of Pollen Dispersal}

The location of the female and the assigned male parents were plotted in the map of adult individuals generated by Garmin MapSource GPS mapping software version 76C5x. The distance between the known female parent and the assigned male parent was calculated using the same software. The distances and positions of both female and male parents in the generated map was then used to ilustrate pattern of pollen dispersal in the location. Self pollination was defined if the assigned male parent was the same as the female parent. Otherwise, they were assigned as outcrossing. The outcrossing were further 
grouped as outcrossing between either dwarf (dwarf parent pollinated other dwarf), tall (tall parent pollinated other tall), or hybrid (hybrid parent pollinated other hybrid); outcrossing between dwarf and either tall or hybrid (either tall or hybrid parent pollinated by dwarf); outcrossing between tall by hybrid coconuts (tall parent pollinated hybrid) or vice versa. The numbers of both self pollination and the respective cross pollination were calculated.

\section{Results and discussion}

\section{The Parents and Progeny Arrays}

Map of the existing coconut palms in the research site are presented in Fig. 1. As indicated, the sample coconut population consists of a mixture of normal homozygous KK and kopyor heterozygous $\mathrm{Kk}$ individuals and a mixture of dwarf, tall and hybrid coconuts. All of these adult trees were used as potential male parents capable of donating pollens to and pollinating the selected female parents and generating the evaluated progeny arrays. The position of the selected female parents ( 6 dwarf, 7 tall, and 2 hybrid kopyor heterozygous $\mathrm{Kk}$ coconuts) are indicated in Fig. 1. The harvested progenies from selected female parents ranged from 2-10 progenies per female parent. Out of 84 selected progenies, 21 were kopyor nuts and 63 were normal ones. They were harvested from tall (26 progenies), dwarf (45 progenies), and hybrid (13 progenies) female parents, respectively.

\section{Genotyping of Parents and Progeny Arrays}

The selected SSR and SNAP marker loci generated polymorphic markers in the evaluated coconut population. An example of the polymorphic marker generated by either the selected SSR (CnCir_56 locus) and SNAP (SUS 1_3 locus) primer pairs producing polimorphic markers is presented in Fig. 2. and 3. In Fig. 2, the evaluated individuals are either homozygous cc (sample \#1), bb (sample \#7-10), heterozygous bc (sample \# 2-6, and 11), or heterozygous ab (sample \# 12) for the CnCir_56 SSR locus. On the other hand, the evaluated individuals (sample $\# 1,3,4,6)$ are heterozygous for reference and alternate SNAP alleles and the other two (sample \# 2 and 5) are homozygous for the reference allele (Fig. 3). All individuals were genotyped using the same approaches. The summary of genotping results for a total of 179 individuals using six SSR and four SNAP marker loci are presented in Table 1. The marker loci generated a range of 2-4 alleles per locus (Table 1).

Mean number of alleles per locus is 3.4 and mean PIC for all marker loci was 0.47. The polymorphic information content (PIC) for SSR marker loci ranges from 0.31-0.68 while that of SNAP markers ranges from 0.28-0.37 (Table 1). The PIC values represents measures of polimorphism between genotypes in a locus using information of the allele numbers (Sajib et al. 2012). Total exclusionary power using the ten marker loci is either 0.85 (first parent) or 0.97 (second parent), indicating the SSR and SNAP markers should be informative enough for analyzing the evaluated coconut population.

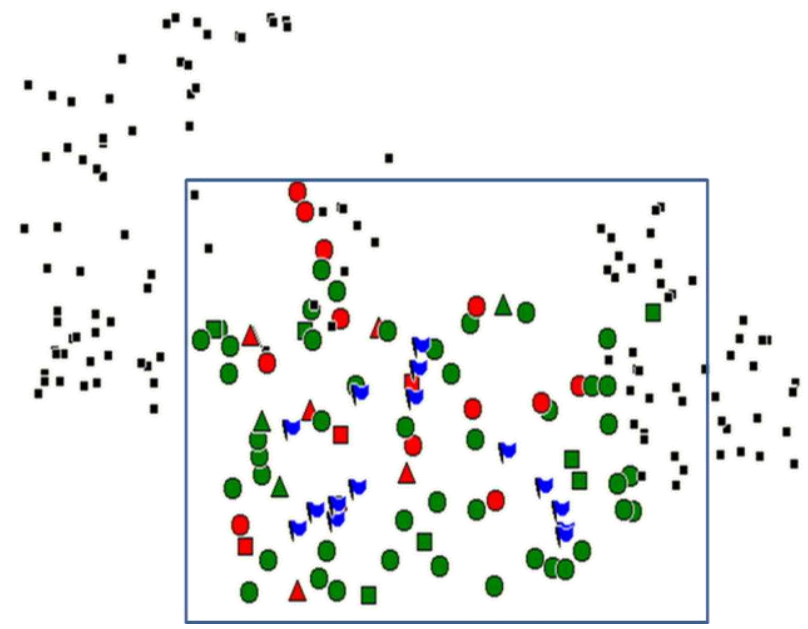

Figure1. Map of study site with the existed coconut palms at Pati, Central Java, Indonesia. The marks in this map indicated the positions of the coconut provenances. The sampled provenances in an approximately one hectare area are in the square box. The flags indicate the positions of the selected female parents.

Note: The marks indicate the position

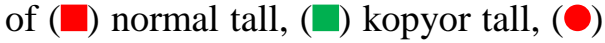
normal dwarf, (O) kopyor dwarf, ( $\mathbf{(})$ normal hybrid, and ( $\boldsymbol{\Delta})$ kopyor hybrid coconuts, respectively. 


\section{$\begin{array}{lllllllllllll}1 & 2 & 3 & 4 & 5 & 6 & 7 & 8 & 9 & 10 & 11 & 12 & M\end{array}$}

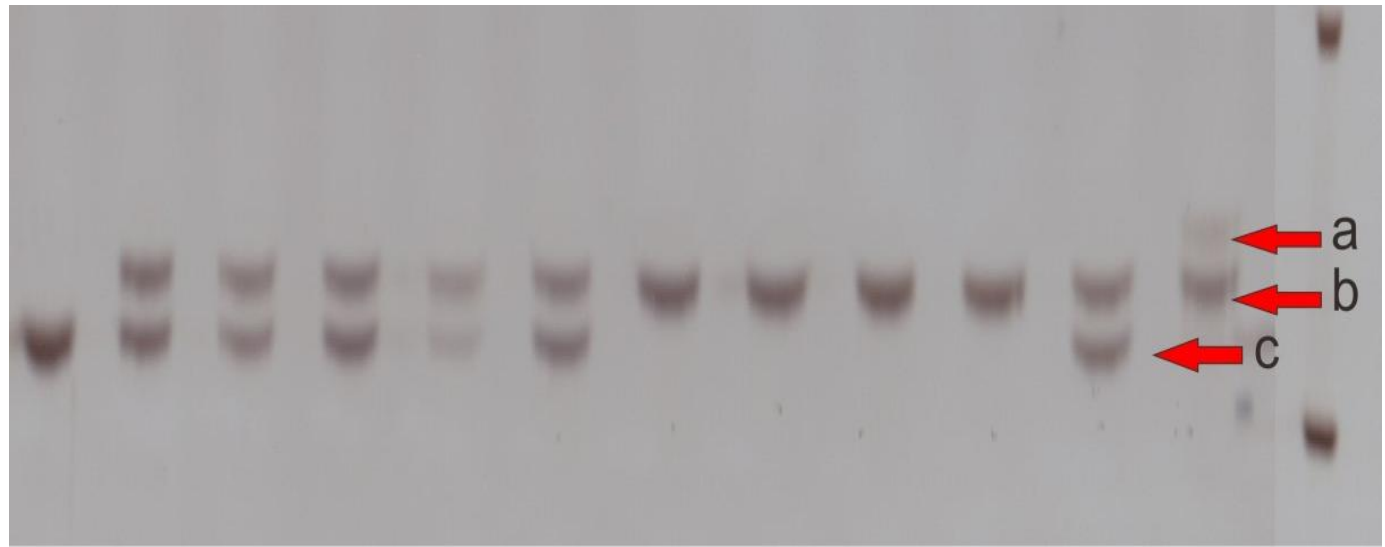

Figure 2. Polymorphism of SSR markers generated by PCR of the genomic DNA sample \#1-12 with a pair of CnCir_56 SSR primers. M: 100 bp DNA ladder markers. The a, b, and c are the three specific alleles of the CnCir_56 locus

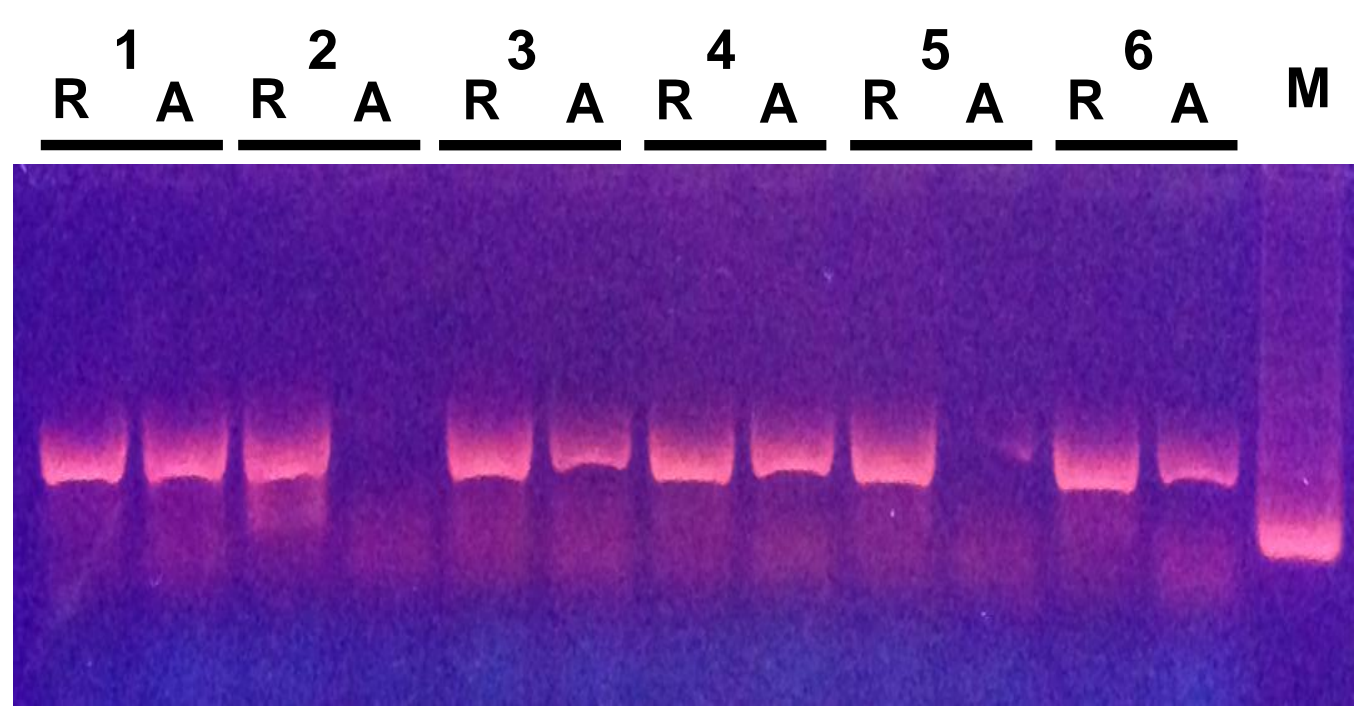

Figure 3. Polymorphism of SNAP markers generated by PCR of the genomic DNA samples 1-6 with two pairs (the R: reference and the A: alternate primer pairs) of the SUS 1_3 SNAP locus. M: 100 bp DNA ladder markers. The RPCR product of the $\mathrm{R}$ primer pairs and the $\mathrm{A}-\mathrm{PCR}$ product of the A primer pairs. The occurrences of both $\mathrm{R}$ and A PCR products indicating the evaluated individuals are heterozygous, while if either onlyA or B indicating they were homozygous 
Table 1. Number of alleles and individuals, heterozygous and homozygous individuals, observed (O) and expected (E) heterozygosity, and polymorphic information content (PIC) at 10 molecular marker loci of Kopyor coconut

\begin{tabular}{|c|c|c|c|c|c|c|c|}
\hline \multirow{2}{*}{ Locus Name } & \multirow{2}{*}{$\begin{array}{l}\text { No. of } \\
\text { alleles }\end{array}$} & \multirow{2}{*}{$\begin{array}{l}\text { No. of } \\
\text { individual }\end{array}$} & \multirow{2}{*}{$\begin{array}{l}\text { No. Of } \\
\text { Hetero- } \\
\text { zygous }\end{array}$} & \multicolumn{3}{|c|}{ Heterozygosity } & \multirow[t]{2}{*}{ PIC } \\
\hline & & & & $\begin{array}{l}\text { Homozy- } \\
\text { gous }\end{array}$ & $\mathrm{O}$ & $\mathrm{E}$ & \\
\hline CnCir_87 & 2 & 179 & 27 & 152 & 0.15 & 0.39 & 0.31 \\
\hline CnCir_86 & 4 & 179 & 100 & 79 & 0.56 & 0.72 & 0.67 \\
\hline CnZ-18 & 4 & 179 & 74 & 105 & 0.41 & 0.61 & 0.57 \\
\hline CnZ_51 & 5 & 179 & 72 & 107 & 0.40 & 0.58 & 0.54 \\
\hline CnCir_B12 & 6 & 176 & 64 & 112 & 0.37 & 0.72 & 0.68 \\
\hline CnCir_56 & 5 & 179 & 78 & 101 & 0.44 & 0.64 & 0.57 \\
\hline CnSus1\#14 & 2 & 179 & 143 & 36 & 0.80 & 0.49 & 0.37 \\
\hline CnSus1\#3 & 2 & 174 & 147 & 27 & 0.85 & 0.50 & 0.37 \\
\hline WRKY19\#1 & 2 & 176 & 111 & 65 & 0.63 & 0.47 & 0.36 \\
\hline WRKY 6\#3 & 2 & 179 & 76 & 103 & 0.43 & 0.34 & 0.28 \\
\hline
\end{tabular}

Table 2. Crossing schemes and pollination types identified based on results of pollen dispersal analysis of the progeny arrays

\begin{tabular}{|c|c|c|c|}
\hline Crossing Scheme & Pollination types & Event numbers & Percentage \\
\hline TxT & Self & 2 & $2.4 \%$ \\
\hline DxD & Self & 13 & $15.7 \%$ \\
\hline $\mathrm{HxH}$ & Self & 0 & 0 \\
\hline \multicolumn{2}{|c|}{ Sub-total Self } & 15 & 17.9 \\
\hline TxT & Outcross & 4 & $4.8 \%$ \\
\hline $\mathrm{TxD}$ & Outcross & 16 & $19.3 \%$ \\
\hline $\mathrm{TxH}$ & Outcross & 4 & $4.8 \%$ \\
\hline DxD & Outcross & 15 & $18.1 \%$ \\
\hline DxT & Outcross & 6 & $7.2 \%$ \\
\hline DxH & Outcross & 11 & $13.3 \%$ \\
\hline $\mathrm{HxH}$ & Outcross & 2 & $2.4 \%$ \\
\hline HxT & Outcross & 0 & 0 \\
\hline $\mathrm{HxD}$ & Outcross & 11 & $13.1 \%$ \\
\hline \multicolumn{2}{|c|}{ Sub-total Outcross } & 69 & $82.1 \%$ \\
\hline \multicolumn{2}{|c|}{ Total progenies } & 84 & $100.0 \%$ \\
\hline
\end{tabular}

Note: $\mathrm{T}$ - tall coconut, $\mathrm{D}$ - dwarf coconut, and $\mathrm{H}$ - hybrid coconut 


\section{Identification of the Candidate Male Parents}

Results of simulation analysis using 10.000 iterations, 95 candidate male parents, and the known female parent for each progeny, predicted the rate of success in identifying male parents at $95 \%$ (strict) was $32 \%$ and at $80 \%$ (relax) confidence interval was $62 \%$. Parentage analysis was able to resolve the identity of the male parent for every individual in the 84 progeny arrays using the most likely parent approach. Moreover, the results of analysis also indicated that assignment of the predicted male parents for the 20\% (17 individuals) progenies are at least in the minimum of $95 \%$ confidence and $43 \%$ (36 individuals) were at least in the minimum of $80 \%$ confidence. The assignment for the male parents of other 57\% (48 individuals) progenies were at the level of less than $80 \%$ confidence. Although the confidence level was below $80 \%$, the male parent assignment for these progenies shows LOD (likelihood of odds) value higher than 0 . A positive LOD value indicates the suspected male parent might be the true parents. According to Marshall et al. (1998), the higher the LOD value the higher the possibility for the assigned male parent to be the actual parent (Marshal et al. 1998).

Cross pollination is pollination of female flower by male pollen from different parents. Cross pollination produces half-sib progenies. The tall, dwarf and hybrid coconuts could reciprocally donate their pollens. Based on the assigned male parent of the 84 progeny arrays, cross pollination occured in as many as 69 events (82.1\%). Among those identified as outcrossing, 4 events are cross pollination between tall x tall (TxT), 16 tall by dwarf (TxD), and 4 tall by hybrid $(\mathrm{TxH})$ parents. Moreover, outcrossing among DxD (15 events), DxT (6 events), DxH (11 events), HxH (2 event) and HxD coconuts (11 events) were also observed. Complete scheme and pollination types identified based on results of pollen dispersal analysis are presented in Table 2 .

The general understanding stated that because of the open flower morphology and the differences in flower maturation, tall coconut is probably always cross pollinated (Ramirez et al. 2004; Maskromo et al. 2011). However, our data indicated there are at least $2.38 \%$ of self pollination among the tall coconut (Table 2).

Self pollination is characterized by the pollination of female flower by male pollen of the same parent. Self pollination produces fullsib progenies. Total numbers of self pollination are observed in as many as 15 events $(17.9 \%)$ in the evaluated progeny arrays (Table 2). They consist of two self pollination events in the tall kopyor coconut $(2.38 \%)$ and 13 self pollination events in the dwarf kopyor one (15.48\%). Based on 13 progeny arrays harvested from the hybrid parents, no self pollination in the hybrid coconut is recorded (Table 2).

The general understanding stated that because of the overlapping period between male and female flower maturation, dwarf coconut is always self pollinated (Maskromo et al. 2011). However, our data indicated the dwarf coconut is not always self pollinated. Contrary to the basic understanding, our data indicated the presence of more dwarf to dwarf (15 events, $17.86 \%$ ), dwarf to tall (6 events, $7.14 \%)$ and dwarf to hybrid (11 events, $13.1 \%$ ) outcrossing (Table 2 ).

Finding by Rajesh et al. (2008) has previously indicated that cross pollination did occur in dwarf coconuts. Availability of new tools, such as molecular markers, for analyzing outcrossing rate may change the previous understanding. Such changes have been shown in Hymenaea coubaril which was previously reported as more cross pollinated because of self incompatibility (Dunphy et al. 2004). However, more recent pollen dispersal studies indicated that $H$. coubaril is more self pollinated (Carneiro et al. 2011).

Other alternative explanation for this findings is that it is just a special case in the evaluated site. In the study site, coconut palms were planted in high density. Moreover, population of honey bees exist in the coconut plantation. Honey bees are known to roam around the male and female flowers and function as effective pollinators for coconuts. The high density planting and the availability of pollinators may have caused the unexpected 


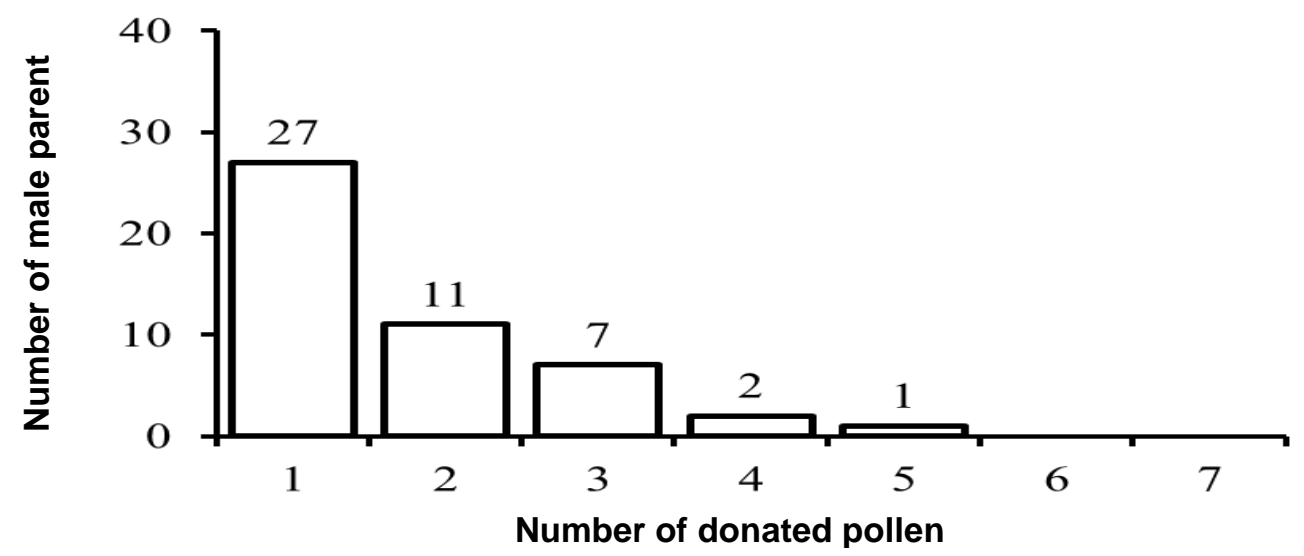

Figure 4. Numbers of assigned male parent donating different numbers of pollen to evaluated female parents

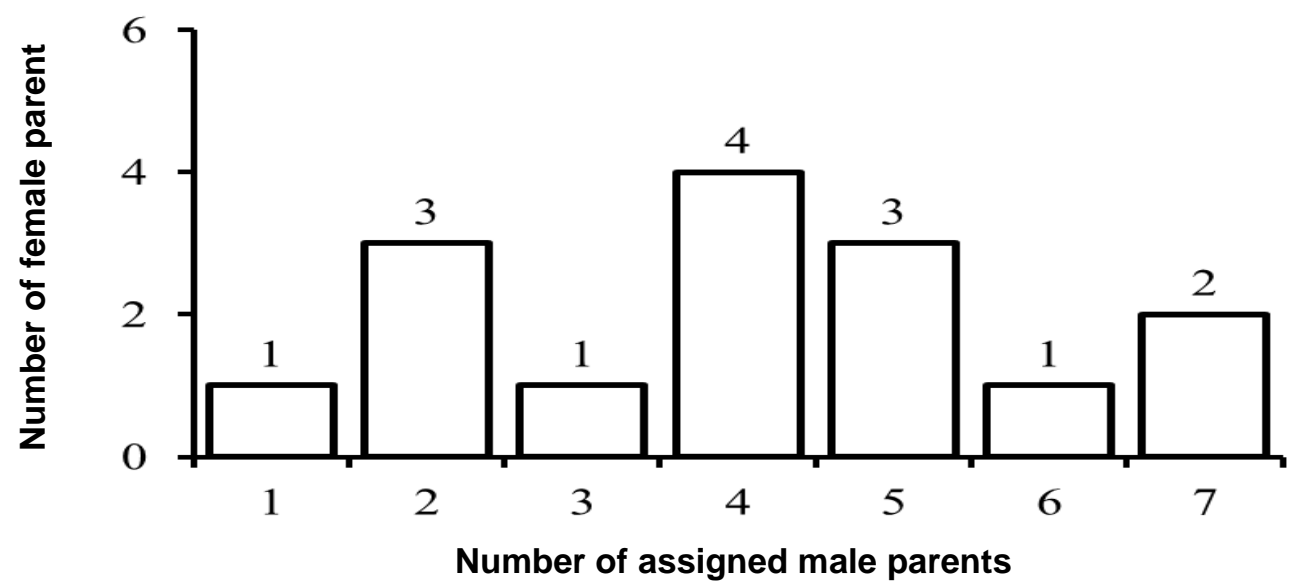

Figure 5. Numbers of female parent receiving donated pollens from different number of assigned male parents

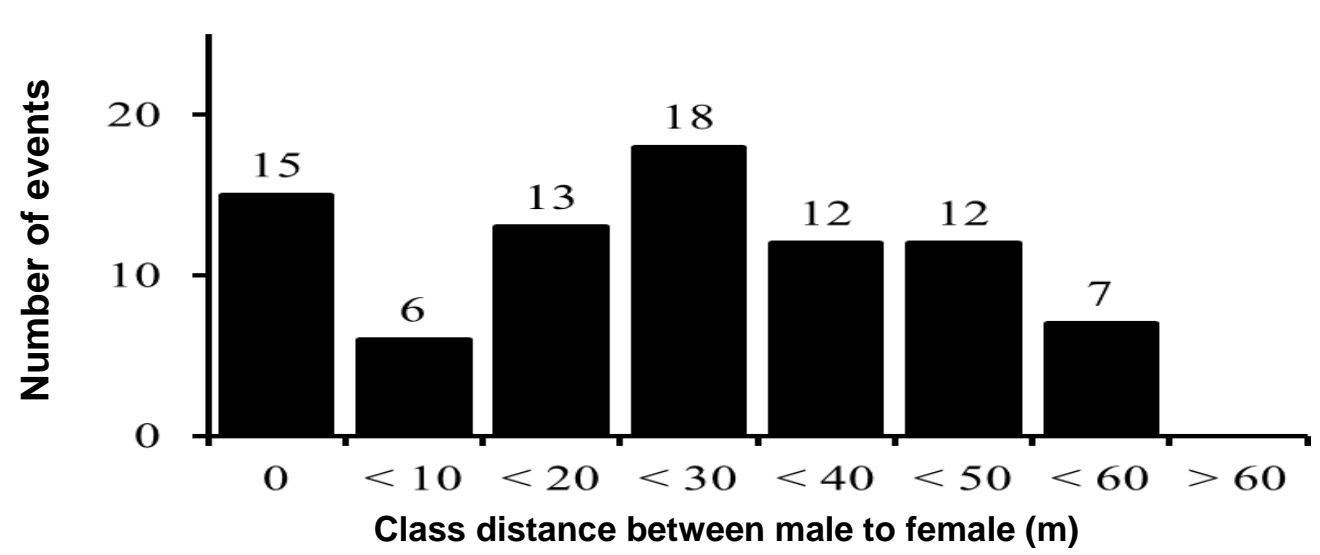

Figure 6. Numbers of pollination events for each distance class from the assigned male to the female coconut parents 
outcrossing rate. However, those are subjects of further investigations.

One assigned male parent may donate one or more pollens to the evaluated female coconut parent, with a range of 1-5 pollens per assigned male one. Number of assigned male parents donating certain numbers of pollen to the evaluated female parents is presented in Fig. 4. The data indicate that most of the assigned male parents contribute only one pollen to the evaluated female parents. Only three assigned male parents (two dwarf, and one hybrid coconuts) donated 4 or 5 pollens to the surrounding female parents.

The same female parents may receive donated pollens from different numbers of assigned male parents, with a ranged of 1-7 assigned male parents donated pollen to the same female one. The numbers female parents receiving donated pollens from different number of assigned male parent iss presented in Fig. 5. The data indicated a single female parent most frequently received pollens from 2,4 or 5 different assigned male parents. Only three female parents evaluated in this experiment (two dwarf and one hybrid coconuts) are found receiving pollens from at least 6 assigned male parents (Fig. 5).

\section{Pattern of Pollen Dispersal}

The distances between female to the assigned male parents have been determined based on their GPS positions. The distance of pollen travel between assigned male to female parents as measured in this evaluation ranged from 0 - $58 \mathrm{~m}$. Numbers of pollination events of each distance class from the assigned male to the female coconut parents are presented in Fig. 6. The assigned male parents are distributed almost evenly in the different class distances from the female parents. The $0 \mathrm{~m}$ distance between parents indicates self pollination events.

To evaluate pattern of pollen dispersal among the assigned male parent to the female, the positions of assigned male parents as pollen donors to one female parent are plotted to a map using their GPS positions. Representative samples of the assigned male parent positions to a single female recipient parent are presented in Figures 7-11.

As the female parent, Hybrid kopyor \# 059 (Fig. 7) received 6 donated pollens from six different assigned pollen donors. The pollen contributors to the progeny array harvested from Hybrid kopyor \# 059 female parent were all kopyor heterozygous Kk coconuts. However, the seven progenies harvested from this female parent were all phenotypically normal, i.e. genetically either a normal heterozygous $\mathrm{Kk}$ or homozygous KK. The positions of the assigned male parents relative to the female parent \# 059 in the study site are presented in Fig. 7.

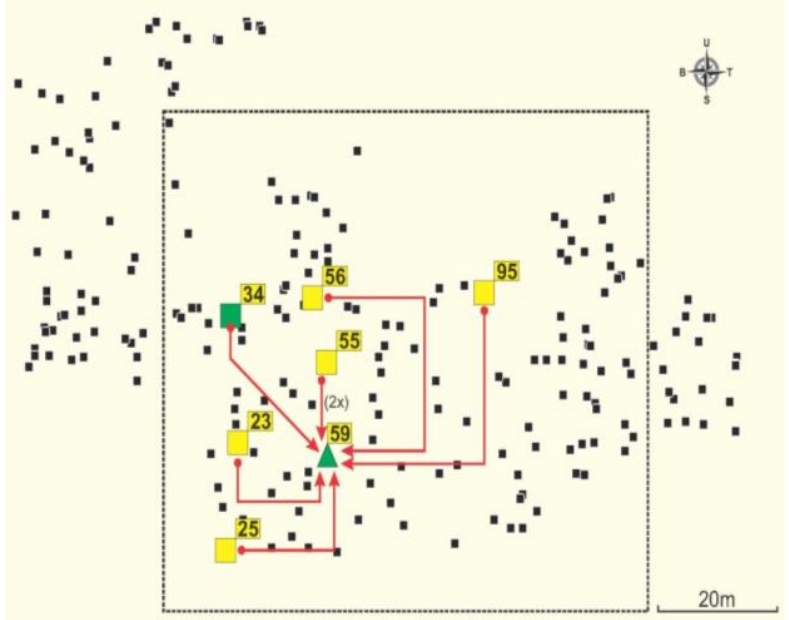

Figure 7. Pattern of pollen movement to female parent \#059 inferred from parentage analysis. The mark indicates position of $(\square)$ Dwarf kopyor, ( $\square$ ) Hybrid kopyor as the assigned male (pollen donor) parents, and $(\Delta)$ hybrid kopyor \#59 as the female recipient, respectively

The Dwarf kopyor \# 067 (Fig. 8) received 10 donated pollens from eight different assigned male parents. The assigned pollen contributors to the Dwarf kopyor \# 067 female parent were all kopyor heterozygous Kk coconuts. Only one out of the 10 progenies harvested from this female parent was phenotypically kopyor. The assigned male parent for the harvested kopyor fruit was the tall kopyor \# 089. The positions of the assigned male parents relative to the female parent \# 067 are presented in Fig. 8. 


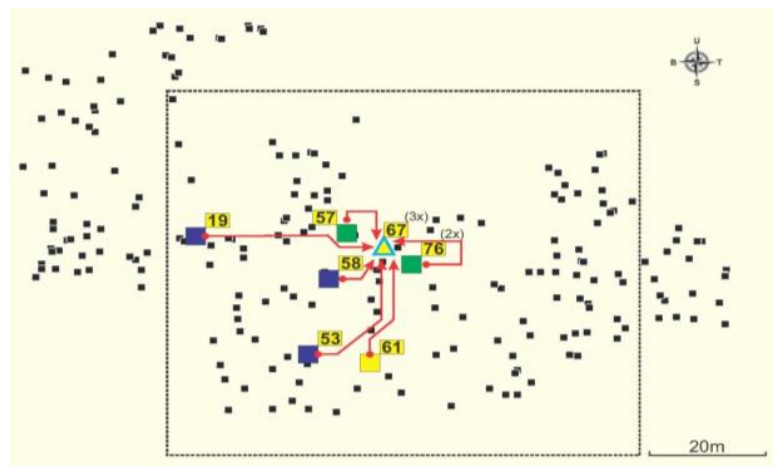

Figure 8. Pattern of pollen movement to female parent \#067 inferred from parentage analysis. The marks indicate position of ( $\square$ ) Dwaf kopyor, ( $\square$ ) Hybrid kopyor, ( $\square$ ) Tall kopyor as the assigned male (pollen donor), and

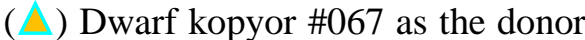
pollens and female recipient, respectively

Dwarf kopyor \# 068 (Fig. 9) received 9 donated pollens from four assigned male parents. The four progenies were the result of outcross with either hybrid (\# 59) or dwarf (\#87 or \# 90) and from self pollination. The assigned pollen contributors to the Dwarf kopyor \# 068 were all kopyor heterozygous Kk coconuts. Three out of the 9 progenies harvested from Dwarf kopyor \# 069 were phenotypically kopyor. These kopyor fruits received one donated pollen from either the tall kopyor \# 059 , dwarf kopyor \# 68 or \# 87. The positions of the assigned male parents relative to the female parent \# 68 are presented in Fig. 9.

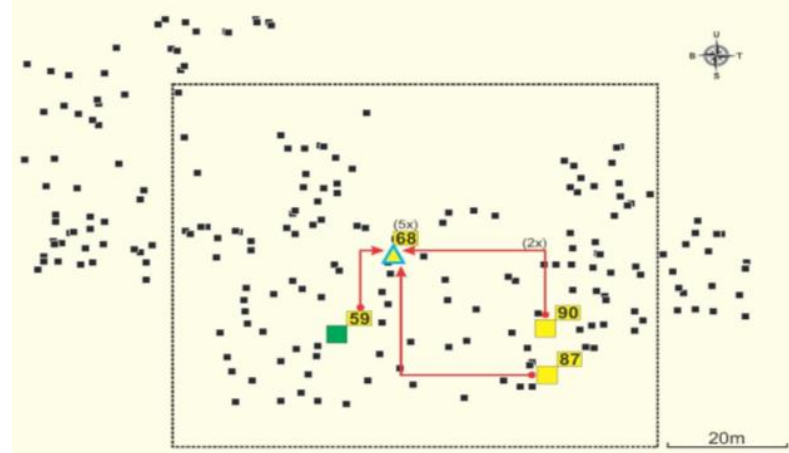

Figure 9. Pattern of pollen movement to female parent \#068 inferred from parentage analysis. The marks indicate position of $(\square)$ Dwarf kopyor and ( $\square$ ) Hybrid kopyor as the assigned male parents (pollen donors), and ( $\triangle$ ) Dwarf kopyor \#068 as the donor pollens and female recipient, respectively

Dwarf kopyor \# 084 (Fig. 10) received 8 donated pollens from surrounding pollen donors. The pollen contributors to the Dwarf kopyor \# 084 female parent were all kopyor coconuts. Only two out of the 8 progenies harvested from Dwarf kopyor \# 084 were phenotypically kopyor. These two kopyor fruits received donated pollens from either The two assigned male parents, either dwarf kopyor \# 056 (one pollen) and hybrid kopyor \# 057 (one pollen), each contributed a one pollen to the evaluated progenies. Moreover, assigned male parent \# 32 is the most distance pollen contributor among the evaluated trees. The positions of the assigned male parents (pollen contributors) relative to the female parent \# 084 are presented in Fig. 10.

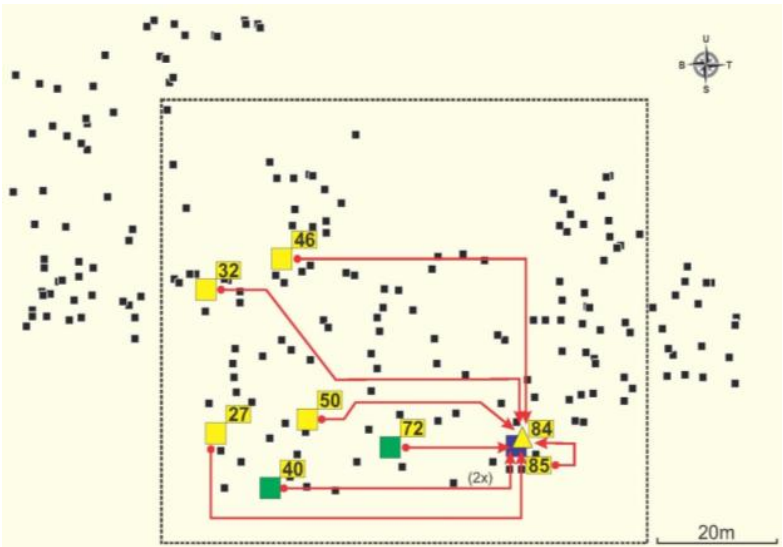

Figure 10. Patterns of pollen movement to female parent \#084 inferred from parentage analysis. The marks indicate positions of $(\square)$ Dwarf kopyor, ( $\square$ ) Hybrid kopyor, ( $\square$ ) the Tall kopyor as the assigned male - pollen donors, and $(\Delta)$ Dwarf kopyor \#84 as the female recipient, respectively

Dwarf kopyor \# 089 (Fig. 11) received 7 donated pollens from surrounding pollen donors. The pollen contributors to the Dwarf kopyor \# 089 female parent were all kopyor coconuts. None of the 7 progenies harvested from Dwarf kopyor \# 089 was phenotypically kopyor. The 
positions of the assigned male parents relative to the female parent \# 089 are presented in Fig. 11.

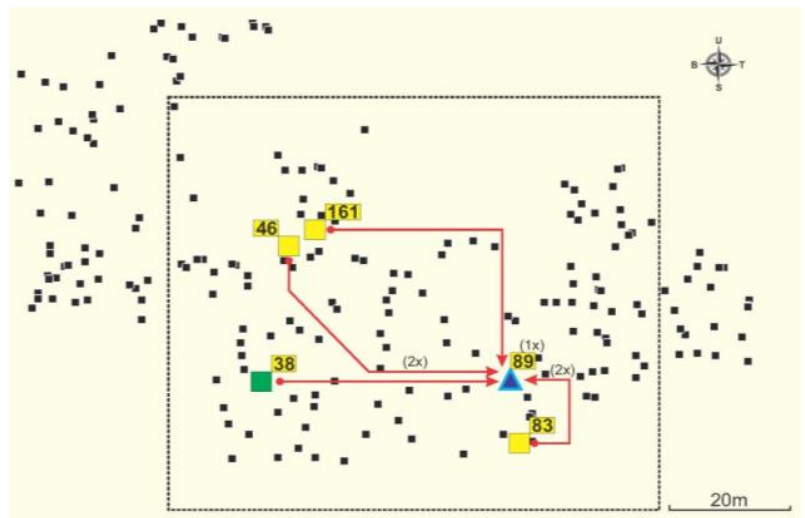

Figure 11. Pattern of pollen dispersal plotted based on the assigned male parent as pollen donor to female parent \#089. The marks indicate position of ( $\square$ ) Dwarf kopyor, ( $\square$ ) the Tall kopyor as the assigned pollen donor, and ( $\boldsymbol{\Delta})$ Tall kopyor \#89 as the donor pollens and female recipient, respectively

Fig. 7-11 indicated that there is no specific direction of donated pollen movement from assigned male parents to the female parents. The donated pollen could come from assigned male parents in any directions relative to the female parent positions.

In the reseach location, wind blows from left to right during the night and from right to left during the day. If the wind is the major pollinators, there should be a specific pattern of pollen movement. Moreover, the distance of pollen dispersals should be close to the pollen donors. Our data did not support the wind as the only major pollinator in Kopyor coconut since pollens disperse in random directions and the assigned male parents are as far as $58 \mathrm{~m}$ apart from the evaluated female recipients. Our data also indicated that insect pollinators may play an important role in Kopyor coconut pollination. Numbers of insects are associated with inflorescence of kopyor coconuts. Such insects may aid pollination and promote cross pollination in kopyor coconuts, as it happens to other plant species (Bown 1988). These findings, however, do not rule out the role of wind in the
Kopyor coconut pollination, especially from closely spacing male pollen donors.

This might have been the first report of using molecular marker to study pollen dispersal in coconut. Results of this study point to new finding about pollen dispersal and pollination, selfing and out-crossing rates among dwarf, hybrid, and tall coconuts, respectively. However, further research and evaluation are necessary to generalize the finding since the present study is specific for the current study site.

\section{Conclusion}

The evaluated markers were effective for assigning candidate male parents to all evaluated seedlings. There is no specific direction of donated pollen movement from assigned donor parents to the female ones. The donated pollens could come from assigned male parents in any directions relative to the female parent positions. Based on the assigned male parent of the 84 progeny arrays, cross pollination occured in as many as 69 events $(82.1 \%)$ including one among tall by tall (TxT), dwarf by dwarf (DxD) and hybrid by hybrid $(\mathrm{HxH})$ cross pollination events. Moreover, outcrossing among TxD, TxH, DxH and vice-versa were also observed. This finding also indicated the dwarf coconut is not always self pollinated. The presence of $17.86 \mathrm{DxD}$, $19.05 \% \mathrm{TxD}$ and $13.10 \% \mathrm{HxD}$ were also observed. In Kopyor coconut, the pollens could travel from pollen donors as far as $58 \mathrm{~m}$ apart from the evaluated female recipients. Therefore, insect pollinators may have played an important role in long distance pollen dispersal in Kopyor coconut.

\section{Acknowledgment}

This research was supported by DGHE, MoEC, Republic of Indonesia through "HILINK Kopyor Coconut Project - 2012-2014" entitled "Increasing Kopyor Fruit Yield with the Help of Honey Bee Pollinators and Production of Kopyor true-to-type Seedlings through Control Pollination" coordinated by SDR. This research is used by SHL for her PhD dissertation. SHL was also supported by Graduate Scholarship Program (BPPS) and Hibah Doktor Program, DGHE, MoEC, Republic of Indonesia. 


\section{References}

Austerlitz F, Dick CW, Klein EK, Muratorio SO, Smouse PE, Sork VL. 2004. Using a genetic marker to estimate the pollen dispersal curve. Molecular ecology. 13:937-954.

Bown D. 1988. Aroid: Plants of the arum family. Oregon (US): Timber Press Portland.

Brody Jonathan R, Scott E Kern. 2004. History and principles of conductive media for standard DNA electrophoresis. Analytical Biochemistry 333 (1): 1-13.

Brumfield RT, Beerli P, Nickerson DA, Edwards SV. 2003. The utility of single nucleotide polymorphisms in inferences of population history. Trends Ecol. Evol. $18: 249-256$

Burczyk J, Koralewski T. 2005. Parentage versus two-generation analyses for estimating pollen-mediated gene flow in plant population. Mol Ecol. 14:2525-2537.

Carneiro FS, Lacerda AEB, Lemes MR, Gribel R, Kanashiro M, Wadt LHO, Sebbenn AM. 2011. Effects of selective logging on the mating system and pollen dispersal of Hymenaea courbaril L. (Leguminosae) in the Eastern Brazilian Amazon as revealed by microsatellite analysis. Forest Ecology and Management. 262:1758-1765.

Creste S, Tulmann AN, Figueira A. 2001. Detection of single sequence repeat polymorphism in denaturing polyacrylamide sequencing gels by silver staining. Plant Mol Biol Reporter 19:299306.

Deb Mandal M, Shyamapada M. 2011. Coconut (Cocos nucifera L. - Arecaceae): In health promotion and disease prevention. Asian Pacific Journal of Tropical Medicine. 4(3):241-247.

Dick, C. W., Etchelecu, G. and Austerlitz, F., 2003. Pollen dispersal of tropical tree (Dinizia excels: Fabaceae) by native insects and African honeybees in pristine and fragmented Amazonian rainforest. Mol Ecol. 12:753-764.

Dunphy BK, Hamrick JL, Schwagerl, J. 2004. A comparison of direct and indirect measures of gene flow in the batpollinated tree Hymenaea courbaril in the dry forest life zone of south-western Puerto Rico. Int J Plant Sci. 165: 427-436.

Herrera MM, Alan WM, James WB, David NK, Raymond JS. 2007. Usefulness of WRKY gene-derived markers for assessing genetic population structure: An example with Florida coconut cultivars. Scientia Horticulturae 115:19-26.

Kurniasih Surti. 2012. Pemanfaatan marka molekuler untuk mendukung perakitan kultivar unggul kakao (Theobroma cacao L.) [disertasi]. Bogor (ID): Institut Pertanian Bogor.

Lebrun P, Baudouin L, Bopurdeix T, Konan JL, Barker JHA, Aldam C, Herran A, Ritter E. 2001. Construction of linkage map of the Rennell Island Tall coconut type (Cocos nucifera L.) and QTL analysis for yield characters. Genome. 44:962-970.

Lian C, Miwa M, Hogetsu T. 2001. Outcrossing and paternity analysis of Pinus densiflora (Japanese red pine) by micro-satellite polymorphism. Heredity 87:88-98.

Marshal TC, Slate J, Krilek LEB, Pemberton JM. 1998. Statistical confidence for likehood based paternity inference in nature populations. Mol Ecol. 7:639-655.

Marsico, T.D., Jessica, J.H. and RomeroSaverson, J. 2009. Patterns of seed dispersal and pollen flow Quercus garryana (Fagaceae) following postglacial climatic changes. J. Biogeogr. 36(5):929-941.

Maskromo I, H. Novarianto dan N. Mashud. 2007. Potensi pengembangan kelapa kopyor di Indonesia. Warta Penelitian dan Pengembangan Tanaman Industri Vol 13 No. 1. 
Maskromo I, Novarianto H, Sudarsono. 2011. Fenologi pembungaan tiga varietas kelapa genjah kopyor pati. Di dalam: Roedhy P, Slamet S, Anas D, Nurul K, Dewi S, Sintho WA, editor. Prosiding Seminar PERHORTI Kemandirian Produk Hortikultura untuk Memenuhi Pasar Domestik dan Ekspor; 2011. Nov 23-24; Lembang, Indonesia. Bogor (ID): Perhimpunan Hortikultura Indonesia. Hlm 1002-1010.

Milleron Matias, Unai Lopez de Heredia, Zaida Lorenzo, Ramon Perea, Aikaterini Dounavi, Jesus Alonso, Luis Gil, Nikos Nanos. 2012. Effect of canopy closure on pollen dispersal in a wind-pollinated species (Fagus sylvatica L.). Plant. Ecology. 213:1715-1728.

Morin PA, Luikart G, Wayne RK, The SNP working group. 2004. SNPs in ecology, evolution and conservation. Trends Ecol Evol. 19:208-216.

Novarianto H, Maskromo I, Dinarti D, and Sudarsono. 2014. Production technology for Kopyor coconut seednuts and seedlings in Indonesia. International Journal on Coconut R \& D. 30(2):31-40.

Novarianto, H dan Miftahorrachman. 2000. Koleksi dan konservasi jenis-jenis kelapa unik. Makalah poster dalam Simposium Pengelolalan Plasma nutfah dan Pemuliaan Bandung 22-23 September. Perhimpunan Ilmu Pemuliaan Indonesia.

Prabha SS, Indira EP, Nair PN. 2011. Contemporary gene flow and matting system analysis in natural teak forest using microsatellite markers. Current Science 101 (9):1213-1219.

Rajesh MK, Arunachalam V, Nagarajan P, Lebrun P, Samsudeen K, Thamban C. 2008. Genetic survey of 10 Indian coconut landraces by Simple Sequence Repeats (SSRs). Scientia Horticulturae 118:282287.

Ramirez VM, Tablat VP, Kevan PG, Morillo IR, Harries H, Barrera MF, Villareal DZ.
2004. Mixed mating strategies and pollination by insects and wind in coconut palm (Cocos nucifera L. (Arecaceae)): importance in production and selection. Agricultural and Forest Entomology 6:155-163.

Rohde W, Kullaya A, Rodriguez MJB, and Ritter E. 1995. Genetic analysis of Cocos nucifera $\mathrm{L}$ by PCR amplification of spacer sequences separating a subset of copia-like EcoR1 repetitive elements. J Genet Breed. 49 : 179-186.

Sajib AM, M.M. Hossain, A.T.M.J. Mosnaz, H. Hossain, M.M. Islam, M.S. Ali, SH. Prodhan. 2012. SSR marker-based molecular characterization and genetic diversity analysis of aromatic landreces of rice (Oryza sativa L.). J. BioSci. Biotech 1(2): 107-116.

Sambrook J. and Russel DW. 2001. Molecular cloning: a Laboratory Manual. Third Edition. Cold Spring Harbor Laboratory Press, Cold Spring Harbor, New York.

Samonte LJ, Mendoza EMT, Ilag LL, De La Cruz ND, and Ramirez DA. 1989. Galactomannan degrading enzyme in maturing normal and Makapuno and germinating normal coconut endosperm. Phytochemistry 28:2269-2273.

Santos GA. 1999. Potential use of clonal propagation in coconut improvement program. In Oropeza C, Verdiel JL, Ashburner GR, Cardena R, and Samantha JM (eds.) Current Advances in Coconut Biotechnology - Current Plant Science and Biotechnology in Agriculture. Kluwer Acad. Publ., London. Pp. 419-430.

Schuster WSF, Mitoon JB. 2000. Paternity and gene dispersal in limber pine (Pinus flexilis James). Heredity. 84:348-361.

Soenarsih Sri. 2012. Pala (Myristica spp.) Maluku Utara berdasarkan keragaman morfologi, kandungan atsiri, pendugaan seks tanaman dan analisis marka SSR [disertasi]. Indonesia (ID): Institut Pertanian Bogor. 
Sudarsono, Sudrajad, Novarianto H, Hosang MLA, Dinarti D, Rahayu MR, Maskromo I. 2014. Produksi bibit kopyor true to type dengan persilangan terkontrol dan peningkatan produksi buah kopyor dengan polinator lebah madu. Laporan Akhir Program Hi Link. Bogor (ID): Institut Pertanian Bogor.

Sukendah 2009. Teknologi pembiakan kultur in vitro dan analisis molekuler pada tanaman kelapa kopyor. [disertasi]. Indonesia (ID): Institut Pertanian Bogor

Sutanto A, D. Sukma, C. Hermanto, and Sudarsono. 2014. Isolation and characterization of Resistance Gene Analogue (RGA) from Fusarium resistant banana cultivars. Emirates Journal of Food and Agriculture. 26(6):508-518.

Wattanayothin, S. 2005. The study on curd coconut hybrids. J. TNCEL 1(3):6-7.

Wattanayothin, S. 2010. Variety improvement of Makapuno. Proceedings of the XLIV COCOTECH Meeting, 5-9 July 2010, Samui Island, Thailand. pp. 96-108. 